\title{
熊本高等工業学校本館の復元的研究 RECONSTRUCTION OF THE MAIN BUILDING OF KUMAMOTO JUNIOR COLLEGE OF TECHNOLOGY
}

\author{
磯田桂 史*，伊 藤 重 剛**
}

Keishi ISODA and Juko ITO

\begin{abstract}
Kumamoto Junior College of Technology was founded in 1906 and its main building was built of wood in 1908. It was one of the first western style buildings in modern Kumamoto and played an important role in the history of architectural westernization of the local town in Kyushu. Although there was preserved no drawing of the building, the authors could reconstruct its precise plan and elevation with the analysis of its remaining old simple single-lined plan drawn in 1919-20 and old photographs in several school albums. The building was symmetrical with wings on both ends, twin towers in the middle and mansard roof. The exterior was decorated with rich ornaments as small pediments and arches on the windows, the roof at the main entrance supported by Tuscan style pillars and scrolled arms, fluted parastrades on the corner of the walls, and so forth. Its layout - lecture rooms on the north side and the corridor on the south - was exceptional compared with other schools at that time which were planned by architectural section of the Ministry of Education. The architect was Jirokichi Oota who worked as an engineer of the Ministry of Education. Thus, the present study cleared a part of architectural history of early modern Kumamoto.
\end{abstract}

Keywords: Meiji Era, Kumamoto Junior College of Technology, reconstruction, twin tower, mansard roof 明治時代、熊本高等工業学校、復元、双塔、マンサード屋根

\section{1 高等工業学校設立の経緯と明治末の状況}

明治期、日本は西欧諸国を目標として、近代的工業を育成するた めの様々な試みを行ったが、その基礎的条件として実業教育の必要 性が認識されるようになった。「近代的工業の普及發達には優秀なる 技術者を必要とし之等の人材を豐富に且つ急速に養成する道は、之

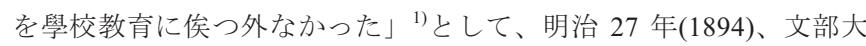
臣井上毅により「實業教育費國庫補助法」をはじめとする実業教育 に関する諸制度の整備が図られた ${ }^{2)}$ 。さらに明治 36 年(1903)3 月 26

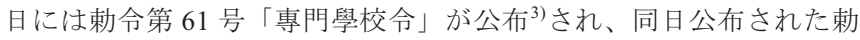
令第 62 号「改正實業學校令」4)では「實業學校ニシテ高等ノ教育 為スモノ 7 實業專門學校卜ス實業專門學校二關シテ八專門學校令, 定ムル所二依ル」とされ、既に設置されていた政府直轄諸学校のう ち工業系では東京高等工業学校、大阪高等工業学校、京都高等工芸 学校が実業専門学校と位置づけられた ${ }^{5}$ 。

その後、工業系の実業専門学校としては、明治 38 年(1905)名古屋 高等工業学校6)、明治 39 年(1906)熊本高等工業学校及び仙台高等工 業学校7)、明治 43 年(1910)米沢高等工業学校及び秋田鉱山専門学校 が設立 ${ }^{8)}$ れた。その一方、明治 45 年(1912)には仙台高等工業学校 が東北帝国大学工学専門部となり ${ }^{9)}$ 、結局、明治末には全国に官立 では工業系専門学校が計 7 校存在していた ${ }^{10)}$ 。

明治政府は日本の工業化を教育分野からも推進し、それを具体的
な形で支えたのが、上記諸学校の建築である。本論文は、5 番目の 高等工業学校として誕生した熊本高等工業学校の本館建築について 論じるものである。

\section{2 既往の研究及び研究の目的}

明治期の高等工業学校や高等師範学校など文部省による学校建築

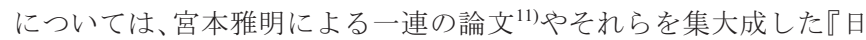
本の大学キャンパス成立史』 ${ }^{12)}$ 、菅野誠著『日本学校建築史』 ${ }^{13)}$ が ある。宮本によれば、明治後期における高等教育機関の建築におい て、設計体制は、企画・計画と設計・監理とが分離して行なわれた ため、キャンパス・プランと建築デザインの計画主体が異なる ${ }^{14)} 、$ 建築デザインは、建築高等教育歴を持たない無名の技術者によって 担われ ${ }^{15)}$ 、工事を担当した技術者ごとにそれぞれ異なったデザイン が展開されるが、共通する部分も多い(16)、とされている。しかし、 宮本の一連の論文等のうち、熊本高等工業学校については断片的に しか触れられていない。また『日本学校建築史』では現存する旧機 械実験工場が紹介されているだけである ${ }^{17)} 。$

一方、文部省直轄諸学校 ${ }^{18)}$ のうち明治後期の本館が現存している のは、奈良女子高等師範学校 (明治 42 年(1909))、米沢高等工業学校 (明治 43 年(1910))、盛岡高等農林学校 (大正元年(1912)) ${ }^{19)}$ の 3 校し かなく、当時の文部省直轄諸学校の建築の特徴を知るには十分と言

\footnotetext{
崇城大学工学部建築学科 准教授

熊本大学大学院自然科学研究科 博士後期課程 ·工修
}

** 熊本大学大学院自然科学研究科 教授·工博
Assoc. Prof., Dept. of Architecture, Faculty of Engineering, Sojo Univ.

Ph. D. Student, Graduate School of Science and Technology, Kumamoto Univ., M. Eng.

Prof., Graduate School of Science and Technology, Kumamoto Univ., Dr. Eng. 
えない状況にある。

そこで、本論文は、後述する現存図をもとに明治 41 年に竣工した 熊本高等工業学校本館の平面図と立面図の復元を試み、その図面や 他の資料を基に、熊本高等工業学校本館の建築的特徴を明らかにし、 さらに、これに携わった設計者及び施工者についても明らかにする ことを目的とする。

\section{3 熊本高等工業学校の誕生までの経緯}

熊本高等工業学校は、明治 39 年(1906)4 月、仙台高等工業学校と ともに全国で 5 番目と 6 番目の高等工業学校として発足した。これ に先立つ明治 30 年(1897)、熊本にあった第五高等学校に工学部が設 置 ${ }^{20)} さ れ 、$ 修業年限は 4 年 ${ }^{21)}$ 、土木工学科と機械工学科が設置 ${ }^{22}$ さ れた。募集人員は各学科およそ 35 名と定められた ${ }^{23)}$ 。校舎は第五高 等学校の敷地内の、本館東側一帯に建設された ${ }^{24)}$ 。

しかし、高等学校が本来帝国大学へ進学する人材を育成する性格 をもっていたのに対し、工学部の学生は卒業後は進学せず技術者と して就職するため、学校内で異質の存在であった。明治 34 年(1901)11 月 26 日付けの第五高等学校から文部大臣にあてた具申書では「工學 部ノ將来二対スル意見」の中に「工學部卜大學豫科卜八其性質自ラ 同ジカラズ教養ノ方法モ亦從ツテ異ラザルヨ得ザルヨ以テ同一ノ規 矩ニヨリ之ヨ管理スルハ工學部ニ對シテモ大學豫科ニ對シテモ兩ツ ナガラ完全ナルコト能ハザル」 ${ }^{25)}$ と述べられ、工学部は早くから分 離の動きがあった。また、現に高等学校に工学部が設置されたのは、 第三高等学校と第五高等学校の二校のみで、第三高等学校の工学部 は明治 33 年(1900)に廃止 ${ }^{26)}$ れ、それ以降第五高等学校にのみ工学 部が存在する状態となり、全国的に見ても異色の存在であった。

明治 39 年(1906)に至り、第五高等学校工学部を改称し 27 、熊本高 等工業学校として独立の実業専門学校となった ${ }^{28)}$ 。熊本高等工業学 校規程 ${ }^{29}$ により、修業年限は 3 年とされ、土木工学科、機械工学科、 採鉱冶金学科の 3 学科が設置された。募集人員は各学科およそ 30 名であった ${ }^{30)}$ 。

\section{4 校舎建設の経緯}

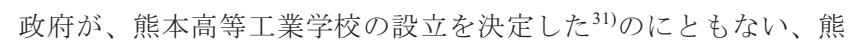
本県は、敷地を寄付することとなった ${ }^{32)}$ 。明治 38 年(1905)末熊本県 知事から内務大臣あて寄付の許可願いが提出され、翌明治 39 年 (1906)3 月に許可 ${ }^{33)}$ となった。一方、政府の明治 39 年度予算では熊 本予學専門学校に 36,063 円が計上された ${ }^{34)}$ 。学校の敷地は、第五高 等学校の南側の道路を挟んだ向かい側となり、熊本県から明治 39 年 11 月 20 日付けで、竣成期限は翌年 3 月 20 日として「敷地地平均 及石垣築設」の入札公告 ${ }^{35}$ が出された。この工事は翌明治 40 年春に は完了した ${ }^{36)}$ 。

明治 39 年 4 月 16 日に文部省建築課長久留正道は、京都、長崎、 名古屋、広島、福岡、熊本の 6 市に出張を命ぜられており ${ }^{37) 、 こ の ~}$ 出張の際、学校当局と校舎建設の方針などについて打ち合わせたも のと考えられる ${ }^{38)}$ 。そして、明治 39 年 11 月 1 日文部省建築課熊本 出張所が開所し、文部技手太田次郎吉ほか数名により校舎の設計が

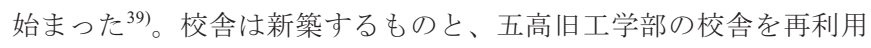
し移築するものとがあった。新築の特別試金室等が明治 41 年(1908)2 月に文部省から学校に引き渡された ${ }^{40)}$ のをはじまりとし、同年 6 月
頃には本館が完成 ${ }^{41)} し 、 7$ 月 1 日には学校の事務所が移転した ${ }^{42)}$ 。 なお、「本館」という用語は、このとき新聞で使われた用語であり、 毎年発行された『熊本高等工業學校一覧』(以下『學校一覧』という。) では「北校舎」、『熊本高等工業學校沿革史』 ${ }^{43}$ ( 以下『沿革史』とい う。)では「教室及び事務室」と記載されているが、これらの用語で はわかりにくいため、以下「本館」という名称を使用することとす る。図書閲覧室等や機械実験工場等も同年から翌年にかけ、文部省 から学校に引き渡された ${ }^{44)}$ この間、久留正道は明治 41 年 11 月 12 日、京都、大阪、名古屋、奈良、福岡、熊本、鹿児島に出張を命ぜ られており ${ }^{45)}$ 、時期的に見て、熊本一の出張の任務は、上記の諸建 物が竣工したことにともなう検查ではないかと推測される ${ }^{46) 。 ま た 、 ~}$ 五高からの移築分も明治 42 年(1909)1 月に引き渡された ${ }^{47)}$ 。そして 食堂等 ${ }^{48)}$ 最後に全ての建物が文部省から学校へ引き渡され、明治 42 年 4 月 17 日の創立記念日に新築校舎落成式が行われた ${ }^{49)}$ 。 この間の詳細は、表 1 の通りである。

表 1 校舎建設の経緯

\begin{tabular}{|l|l|}
\hline \multicolumn{1}{|c|}{ 日 } & \multicolumn{1}{|c|}{ 付 } \\
\hline 明治 39 年 03 月 29 日*1 & 学校設置勅令公布 \\
\hline 明治 39 年 04 月 16 日*1 & 久留正道へ熊本等への出張命令 \\
\hline 明治 39 年 11 月 01 日*2 & 文部省建築課熊本出張所開所 \\
\hline 明治 40 年 05 月 13 日*3 & 熊本県から学校へ、土地引き渡し \\
\hline 明治 41 年 02 月 18 日*3 & 特別試金室電気試金室等引き渡し \\
\hline 明治 41 年 07 月 01 日*4 & 本館竣工し事務所移転 \\
\hline 明治 41 年 09 月 30 日*3 & 教室及び事務室、書庫等引き渡し \\
\hline 明治 41 年 11 月 13 日*1 & 久留正道へ熊本等への出張命令 \\
\hline 明治 41 年 11 月 30 日*3 & 図書閲覧室等引き渡し \\
\hline 明治 42 年 01 月 15 日*3 & (移築)旧工学部建物教室等引渡し \\
\hline 明治 42 年 01 月 15 日*3 & 機械実験工場等引き渡し \\
\hline 明治 42 年 02 月 16 日*3 & 水力実験室等引き渡し \\
\hline 明治 42 年 04 月 12 日*3 & 食堂等引き渡し \\
\hline 明治 42 年 04 月 17 日*3 & 新築校舎落成式 \\
\hline
\end{tabular}

(注)*1「官報」,*2「九州日日新聞」,*3『沿革史』,*4『學校一覧』

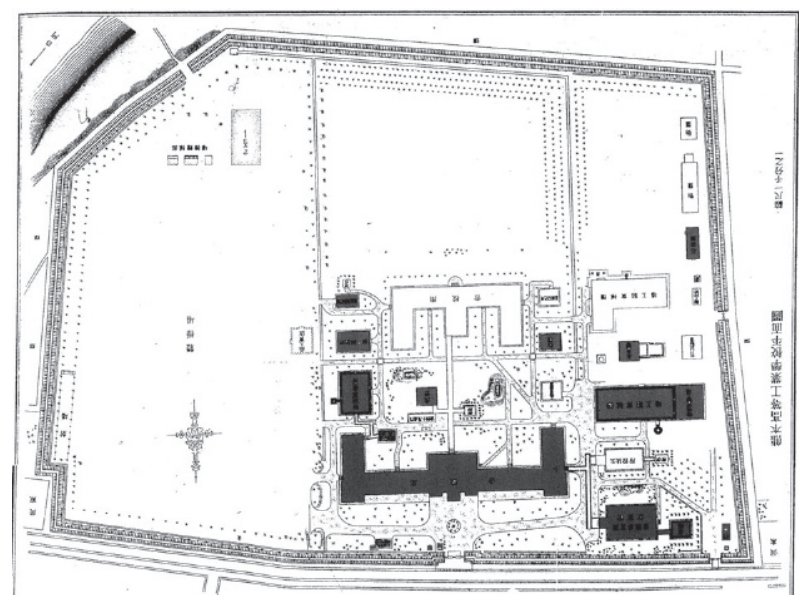

図 1 熊本高等工業学校創建当時の配置図 
図 1 は創建当時の配置図 ${ }^{50)}$ である。なお、後に掲載する図面と方 位をそろえるため南北方向を逆にした。図面の手前が北である。

この図からわかるように、主要な建物である本館(北校舎)、南校舎 はそれぞれ東西方向に並んでいる。なお、新築分については黒塗り としたが、北側の正門を入って目に入るところは殆ど新築分で、移 築分は本館裏側(南側)に配置されていることがわかる

\section{5 現存図面}

\section{5-1 現存図面の概要}

かつての熊本高等工業学校の敷地は、現在の熊本大学南キャンパ スとなっており、その一画に、れんが造の工学部研究資料館 ${ }^{51}$ があ る。これは当時の機械実験工場である。その内部の壁面に「熊本高 等工業學校創立之圖 縮尺二百分之一」という表題が書かれた縦 $1242 \mathrm{~mm}$ 、横 $1602 \mathrm{~mm}$ の図面(図 2)が掲示されている。この図面は着 彩されていたようであるが現在は色あせ、着色は水色に塗られた排 水溝等一部にしか残っていない。この図面に描かれているのは、学 校全体の敷地、各建物の配置兼一階の平面、外構、排水溝等である。 各建物の一階平面はシングルラインで表現されているが、内壁も描 かれ、教室や廊下等の配置がわかる。

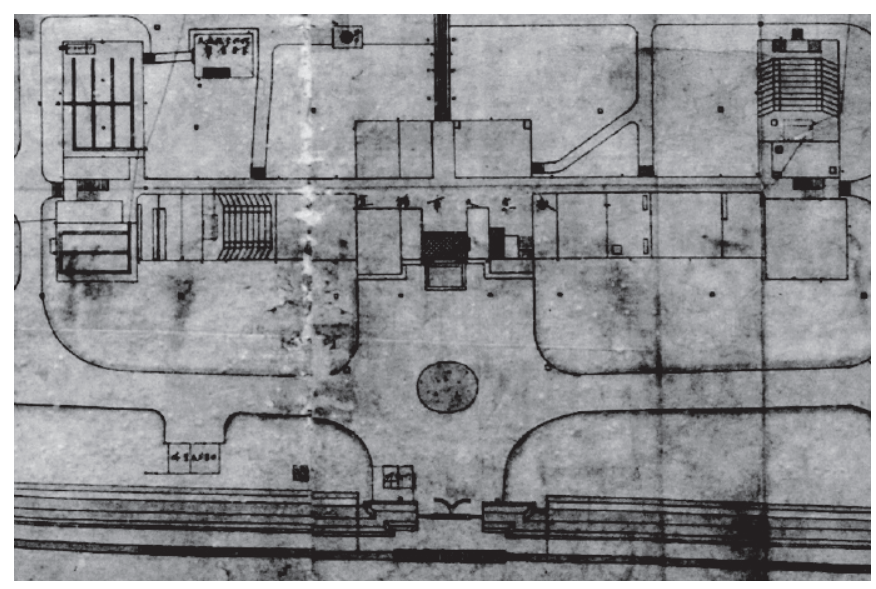

図 2 「熊本高等工業學校創立之図」のうちの本館部分 (熊本大学工学部研究資料館に掲示)

図の左下にある凡例を見ると、「煉瓦造」「木造」という建物の構 造種別のほか、「床張渡廊下」「吒渡廊下」「石材」「木造階段」「石造 階段」「吒又コシクート」「道路」「木橋」「石橋」さらに「便所溜蓋」 「暗渠」「井戸」「排水溝」「排水」「給水」があり、また、凡例には ないが建物周辺に樋の位置も黒点で示され、給排水関係が特に詳し く示されている。また、凡例には、以上の他、県施工として「堤防」 「排水溝」「排水土管」の 3 つが書かれている。前述のとおり、この 土地は熊本県の寄付によるものであり、寄付にあたっては、造成工 事を県が行なっていることから、高等工業側で行なった排水溝等の 外構工事と区別するため、書き分けているものと思われる。

\section{5-2 図面の作成時期}

この掲示された図(以下、この図を「掲示図」という。)の表題に は「創立之圖」と書かれているが、以下その作成時期を検討する。 本館は、大正 11 年(1922) 10 月の火災により焼失 ${ }^{52}$ し、その後鉄筋 コンクリート造の建物が建設される。各年版の『學校一覧』に掲載 されている「平面図」によって、創立当時の木造校舎と火災後の鉄
筋コンクリート造校舎とを比較すると、東西方向の長さや玄関部分 の凹凸、両翼部の南北方向の長さが異なっている。それによると掲 示図では焼失前の本館が描かれているので、掲示図の作成は大正 11 年以前であることになる。

次に創立から本館の焼失までの間で、敷地内の大きな動きとして は南側の新校舎の建設があるが、この掲示図にはその新校舎が描か れているため、掲示図の作成はそれ以降であることになる。この新 校舎は電気工学科の設置にともない建設されたもので、大正 7 年 (1918)4 月に電気工学科の最初の入学生が入ってきた時点では、建物 は工事中であった ${ }^{53)}$ 。完成は大正 7 年 6 月 30 日とされる ${ }^{54)}$

この他、水力実験室や機械実験工場、学生控所は、従前から存在 したがこのころ増築されており、揭示図中に書かれたそれらの施設 の図は、『学校一覧』の「平面図」では大正 8 年版に初出の図と一致 している。また、それらは『學校一覧』の「土地及建物表」では大 正 9 年版(大正 9 年 3 月 31 日現在)に初めて掲載される。

以上から、この掲示図は大正 8 年(1919)から 9 年(1920)の頃の状況 を表しているものと考えられる。

また、各年版の『學校一覧』に掲載された記事、写真、配置図、 建物一覧により、掲示図の本館は明治 41 年(1908)創建当初の外形を 表していることがわかる。

\section{5-3 掲示図の信頼度}

この掲示図は様々な大きさの 12 枚の用紙を継ぎ合わせて作成さ れ、かつ一部は上に張り重㸚てある箇所もある。継ぎ目をまたがる とやや不正確となり、後に述べるように本館部分には 2 ヶ所継ぎ目 があり、その結果図示された寸法が縮んでいる。

現存する機械実験工場は、掲示図では継ぎ目をまたがっていない ので、掲示図と現存する機械実験工場内部に立つ独立柱 5 スパン間 の寸法とを比較してみると、実際の寸法 $13.1 \mathrm{~m}$ の部分に対し掲示図 から読み取った寸法を実寸にした寸法は $12.9 \mathrm{~m}$ であり、1.6\%程度の 誤差となっている。ここではこの程度の誤差があり得ること及び継 ぎ目では寸法が縮んでいることを前提に、この掲示図より寸法を読 み取って、本館の平面図の作成を試みる。

\section{6 本館図面の復元}

\section{6-1 復元のための参考資料}

以下、上記の掲示図及び熊本大学工学部研究資料館所蔵の卒業ア ルバム等の写真を基にした本館の平面図及び立面図の作成作業の概 要を示す。参考にした図面は、文部省直轄諸学校のなかでほぼ同時 期に工事が行われた建物のうち詳細がわかる図面が入手できた熊本 高等工業学校講堂兼図書閲覧室(明治 41 年(1908)竣工)の移築時の実 測図面 ${ }^{55}$ 、米沢高等工業学校本館(明治 43 年(1910)竣工)の修理工事 報告書 ${ }^{56}$ 、盛岡高等農林学校本館(大正元年(1912)竣工)の改修設計図 57)である。また、参考にした写真は、卒業アルバムの写真や『學校 一覧』等の資料 ${ }^{58}$ に掲載された外観が写っているもの合計 38 枚であ る。この他屋内写真も 25 枚存在する。

\section{6-2 1 階平面図の作成について}

本館と同時に建設された講堂兼図書閲覧室は、昭和 51 年(1976)、 その一部が移築され現存しているがその移築前の実測図 ${ }^{59}$ から

$1818 \mathrm{~mm}$ を単位寸法としていると考えられ、また同時代に建設され た米沢高等工業学校の本館においても $1818 \mathrm{~mm}$ が単位として使われ 


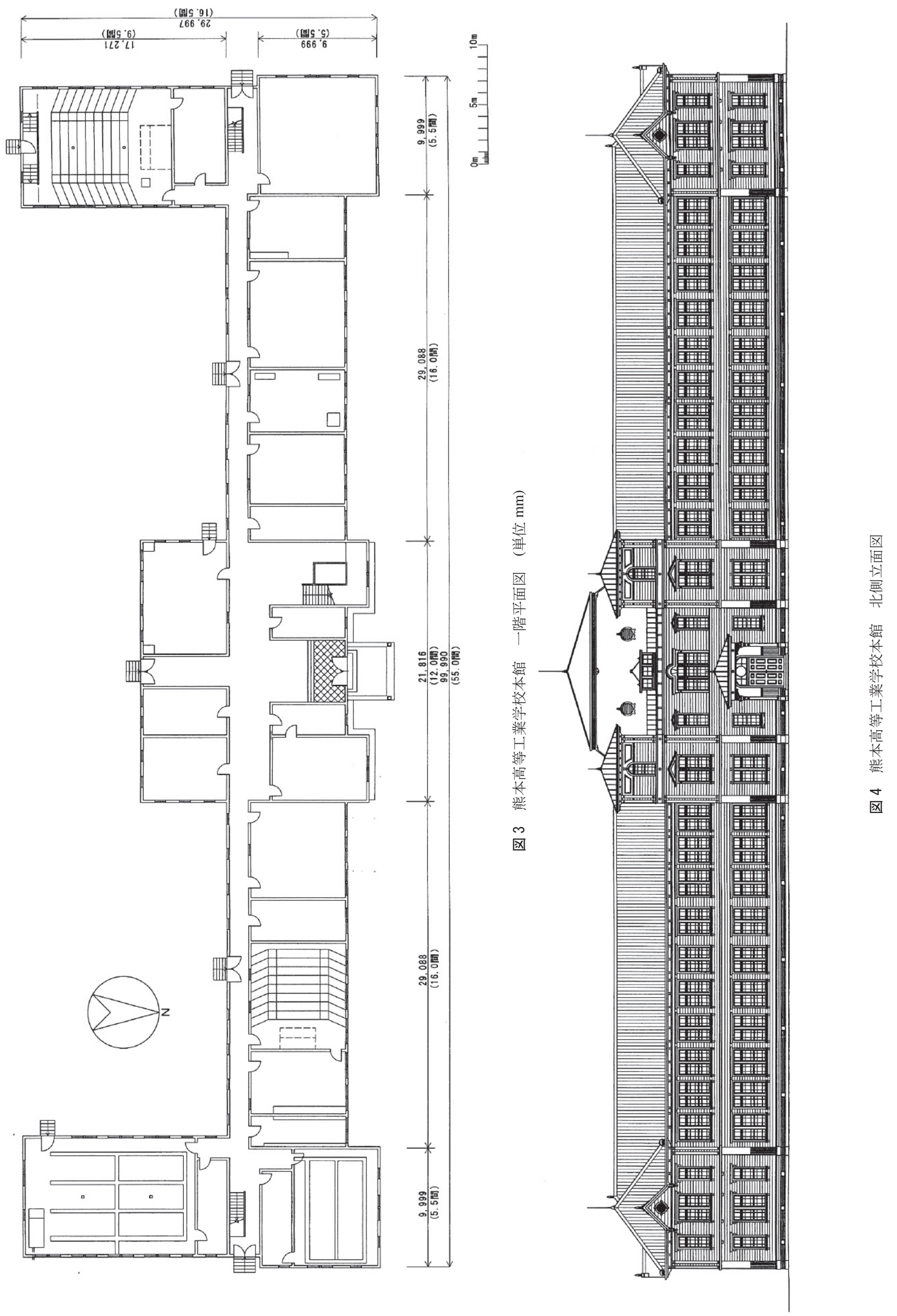




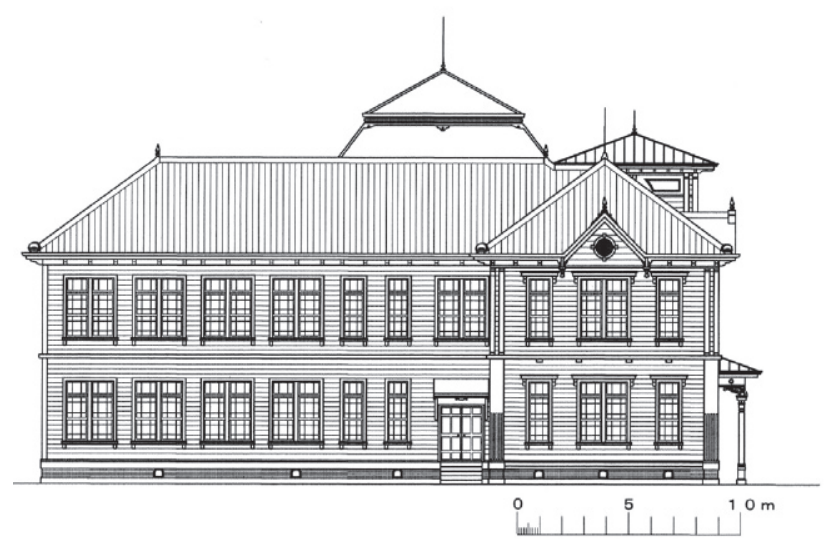

図 5 熊本高等工業学校本館東側立面図

ている ${ }^{60)}$ 。掲示図から読み取った数值も $1818 \mathrm{~mm}$ を単位とすると多 くの場合切りのいい数值となることから、1818mmを 1 間とする寸 法が使われているものとして図面を作成した。

掲示図で玄関部と翼屋の間の部分 (以下、「胴家」という。また「玄 関部」を「中央家」、翼屋を「翼家」という ${ }^{61)}$ 。) を横切る東西 2 ヶ 所にある紙の継ぎ目部分では、それをまたがる方向(桁行方向)の寸 法を 1 間単位で切りのいい寸法となるように引き伸ばした ${ }^{62)}$ 。また、 東側の胴家の継ぎ目部分には内壁が見えないが、空の配置状況から 内壁の存在が考えられることから、それを補った。建築面積を算出 すると玄関ポーチを含め 481 坪となり、『沿革史』の数值 ${ }^{63)}$ 及び『學 校一覧』の数值と一致することから、以上の操作は妥当なものと考 えられる。

空の寸法は、尺単位で割り切れる寸法を設定し、写真と整合する ように二連空の内法幅を $2121 \mathrm{~mm}$ とし、単空の幅の内法を $909 \mathrm{~mm}$ と した。写真を見ると胴家の空は等間隔に配置されているわけではな

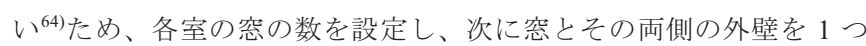
の単位としてそれらを各室に均等に配置した。なお、空には単空

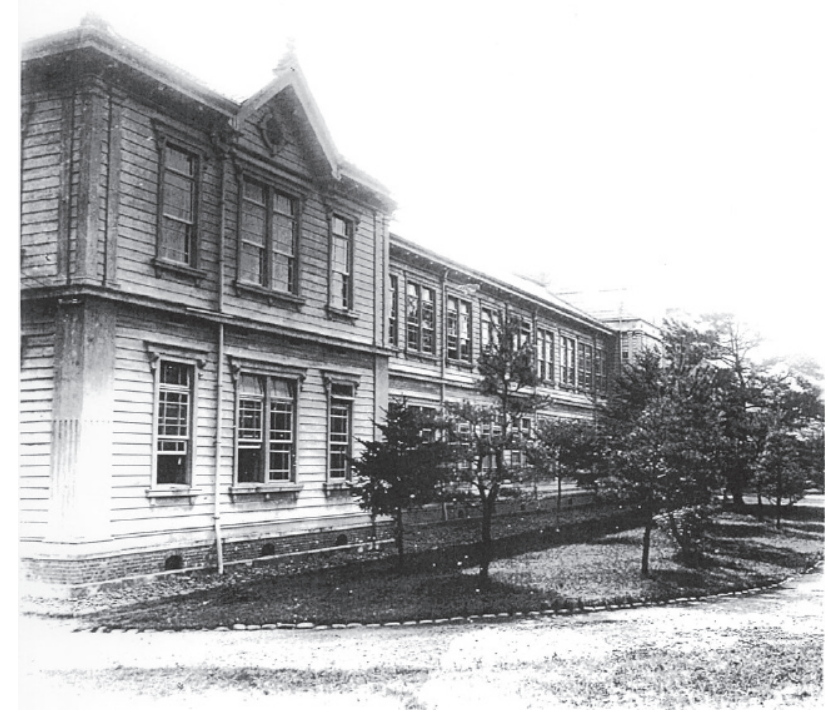

図 6 熊本高等工業学校本館(冨重利平による写真)
と二連空の 2 種類の空があるが、それぞれ等しい寸法とした。結果 を写真と比較するとほぼ同様に見える。

一方内部については、写真から廊下と各室との出入口は内開戸で あり、かつ空があったことが確認できる。全ての部屋の内部写真が あるわけではないが、これらの内部写真を基に五高記念館及び米沢 高等工業学校の図面を参考に、出入口と空を設定した。

このようにして作成した平面図が図 3 である。

\section{6-3 北側及び東側立面図の作成について}

本館については前述したように様々な写真があり、その中の図 $6^{65)}$ 等の写真を透視図と見なし、平面図と照らし合わせながら、図学 的方法により、北側及び東側立面図を作成した ${ }^{66)}$ 。それが図 4 及び 図 5 である。平面図を作成した場合の掲示図に相当する図面や建築 面積 481 坪に相当する復元の目標とす心゙き值が見つからないこと、 基準とすべきレベルの高さが不明であること等の課題はあるが、図 6 に写っている手前の翼家部分の地面の高さを一応の基準の高さ $( \pm$ $0 \mathrm{~m})$ として作図した。この図によれば胴家及び翼家における棟瓦上 端の高さは $14.7 \mathrm{~m}(48.5$ 尺)、軒の高さにほぼ相当すると考えられるモ ディリオン上端の高さは $10.1 \mathrm{~m}$ (33.4 尺)、中央家における棟の高さは $18.6 \mathrm{~m}$ (61.5 尺)、玄関脇の塔の部分の棟の高さは $15.8 \mathrm{~m}$ (52.2 尺)、モ ディリオン上端の高さは $14.2 \mathrm{~m}$ (47.0 尺)となった。また空の 1 階の高 さ方向の寸法は欄間共 $2705 \mathrm{~mm}$ (8.9 尺)、2 階は $2667 \mathrm{~mm}$ (8.8 尺)であ る。基䃈はれんが 6 段積みであり、この高さ方向の寸法は $404 \mathrm{~mm}$ と なった。現存する機械実験工場の 6 段分の寸法は上下の目地を含め $401 \mathrm{~mm}$-407mmであり、ほぼ妥当な寸法と考えられる。

\section{7 本館の特徵}

掲示図や上述のようにして復元した図面及び写真に基づき、その 特徵を以下に述べる。

\section{7-1 平面計画について}

掲示図を読み取ると、平面は東西に長く、両端に翼家がある。ま た、道路が北側にあることから北向きが正面である。中央家に車寄 せを設け主出入口とし、2 階への階段は中央家に 1 ケ所、東西の翼 家にそれぞれ 1 ケ所、計 3 个所ある。一方、復元図によれば、東西 の長さは 55 間ほぼ 100m の長さがあり、胴家部分の梁間方向(南北 方向)の寸法は 5.5 間、翼家の梁間方向(東西方向)の寸法も 5.5 間で あり、建築面積は前述のように 481 坪である。また、正確に左右対 称の平面を持つ。

掲示図では、部屋は中央家に事務室と思われるもの 6 室、胴家に は東側に 4 室、西側に 5 室、翼家には東側 4 室、西側 3 室があるが、 復元作業の際、東側胴家には前述のように写真の空の配置から紙の 継ぎ目部分に内壁の存在が考えられることから、内壁を追加し 1 室 増加したため復元図では計 5 室となった。

掲示図では階段教室が 2 室あり、 1 室は西側翼家の南側、 1 室は東 側の胴家にある。大正 9 年 3 月の機械工学科卒業記念アルバムにあ る化学講義という説明がつけられた写真の階段教室は空の配置から 東側の胴家の階段教室と考えられる。大正 10 年土木工学科卒業記念 アルバムに掲載された階段教室は、同様に空の配置から西の翼家の 階段教室と考えられる。また掲示図の東側翼家の 2 教室内にはいず れも水色に着彩された排水溝と思われるものが描かれている。この うち南側の教室は、空、内部の独立柱及び実験装置の配置状況から、 
大正 2 年版『学校一覧』のグラビアに掲載された採鉱治金学科分析 室と考えられる。

ところで、この建物の大きな特徴は廊下が南側にあることである。 明治 20 年代、高等中学が文部省により建設され始めてから以降の文 部省直轄諸学校(以下、各学校の名称は明治末当時とし、熊本高等工 業以外は略称を用いる)の本館を、宮本雅明『日本の大学キャンパス 成立史』 ${ }^{67}$ に掲載された平面図によりみてみると、棟の方向が東西 に配置された三高(当初のもの及び移転後のもの双方)、四高、長崎 高商、八高、米沢高工、東京高師の全てが北側廊下になっていて、 唯一の例外が熊本の五高である。このほか上記の本には採録されて いないが、各学校の『學校一覧』に掲載された図面や記念誌等の資 料により明治末まで完成していたものをみると、棟の方向が東西で ある本館のうち仙台高工、神戸高商、京都高工、東京盲が北側廊下 であるのに対し明治 24 年(1891)の長崎医専(旧五高医学部)、明治 25 年(1892)の金沢医専(旧四高医学部)、明治 41 年(1908)の熊本高等工 業においては南側廊下となっている。次に述べる文部省の方針が打 ち出される以前の金沢、長崎の両医専を別にすれば明治 41 年建設の 熊本高等工業の特異性が浮き彫りとなる。なお、棟の方向が東西方 向から $45^{\circ}$ 程度振れたもので片廊下のものが東京高工、東京音楽、 東京壟唖の 3 校あり、このうち明治 36 年の東京高工の廊下は南側に ある。

菅野誠『日本学校建築史』 ${ }^{68}$ によれば、明治 28 年(1895)4 月出さ

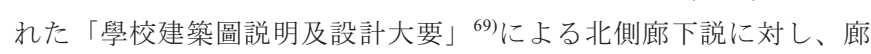
下は北側がよいか南側がよいか論争となり、明治 34 年 4 月 8 日付け 官報に三島通良の「校舎衛生上ノ利害調查」 ${ }^{70}$ )が掲載され、その後 北側廊下で全国統一されてしまった。青木正夫によれば、全国統一 される前、熊本と高知は南側廊下説を強硬に主張していた ${ }^{71)}$ とある。 これらは主として小学校の校舎に関する議論であり、その影響の有 無はわからないが、熊本高等工業本館においては五高本館を踏襲す るかの如く、南側廊下となっている ${ }^{72)}$

\section{7-2 平面計画の寸法}

前述したようにこの建物では $1818 \mathrm{~mm}$ を 1 間とする寸法単位が使わ れていると考えられる。以下平面の寸法を間単位で示す。図 3 では、 本館全体の東西方向の長さは 55 間であり、その内訳は中央家部分が 12 間、東西の胴家部分がそれぞれ 16 間、東西の翼家部分がそれぞ れ 5.5 間である。南北方向の寸法は、中央家が、出入口部分で 9.5

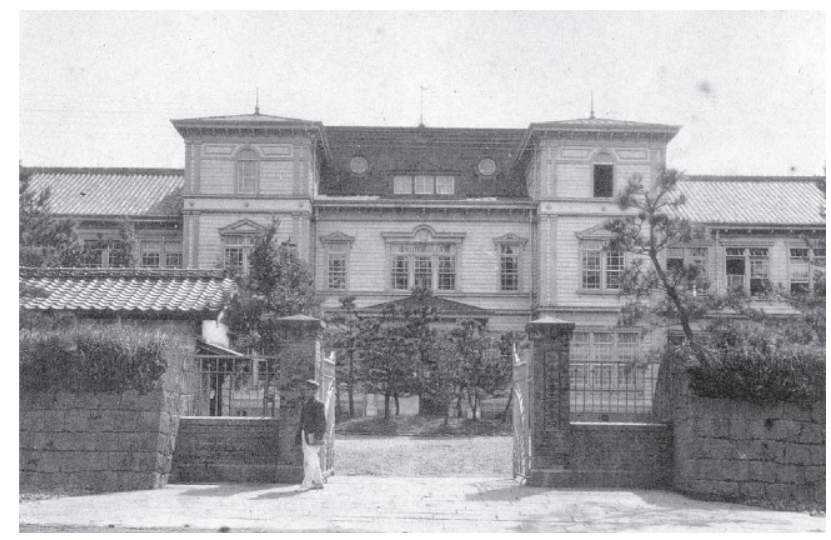

図 7 熊本高等工業学校本館 (大正時代)
間、塔の部分で 10.5 間、胴家(梁間方向)が 5.5 間で、このうち教室 部分が 4.5 間、廊下部分が 1 間である。さらに翼家(桁行方向) は全 体で 16.5 間である。このうち主要な寸法を図 3 に示す。

各室の寸法を見ると、中央家部分では、南側 3 室はいずれの部屋 も南北方向は 4 間、東西方向は東側から 3 間、 2.25 間、 5.25 間であ る。そして中央部分にある通路の幅が 1.5 間である。北側の部屋は 正面出入口の両側の小部屋がそれぞれ東西方向 1.5 間南北方向 3.5 間、東の部屋が東西方向 3 間南北方向 4.5 間である。胴家部分の各 室では上述のように南北方向 (梁間方向) が 4.5 間であり、東西方向 には、東側胴家部分が東側から 1.5 間、3 間、5 間、2 間、4.5 間、 西側胴家部分が東から 1 間 4 尺、 3 間 2 尺 ( 2 室の合計で 5 間)、 3 間、 5 間、 3 間である。翼家は東西とも東西方向は 5.5 間であり、東側翼 家で北側の部屋が南北方向 4 間、南側の部屋が 8 間であり、その両 室に東西方向 4.5 間南北方向 1.5 間の準備室と思われる小部屋がつ いている。西側翼家は北側の部屋が東西方向南北方向とも 5.5 間、 南側の部屋が東西方向 5.5 間南北方向 7 間の部屋に東西方向 4.5 間 南北方向 2.5 間の小部屋がついている。

\section{7-3 ファサードについて}

前述の写真(図 6、7 等)を観察した結果、以下のことが判明した。 また、図4の中央家と翼家部分を拡大したものが図 9 及び 10 である。 ファサードは、胴家部分の空の配置以外は左右対称である。壁面は 下見板張り、空は上げ下げ空、基礎にはれんがを 6 段積んでいる。 屋根は、中央家の玄関ポーチ及び両脇の塔の宝形屋根、翼家の小破 風部分は鉄板莫き、それ以外は栈瓦葺きと考えられる。中央家のマ ンサード屋根は上部鉄板莫き下部スレート莫きと考えられるが、写 真では判別できない。

中央家の主出入口には宝形の屋根を持つポーチをつけ、柱台のあ るトスカナ風角柱で支えている。角柱の上部には横向きの渦型持ち 送り(図 8)をつけ、フリーズを支える。そのフリーズには 3 つの小 な円形の装飾がついている。正面二階には中央に 3 連空があり、そ の中央の空の上部にはアーチがある。その中央の 3 連空から離れた 両側にはペディメントをつけた単空がある。

正面の両側には北側にやや突き出して 3 階建ての塔(以下この二 つの塔を「双塔」という。)を建て宝形の屋根を乗せている、1 階は 2 連空 ${ }^{73)} 、 2$ 階はペディメントをつけた 2 連空、3 階は半円アーチを つけた単空がある。隅角部は、1 階が下半分にフルーティングのつ

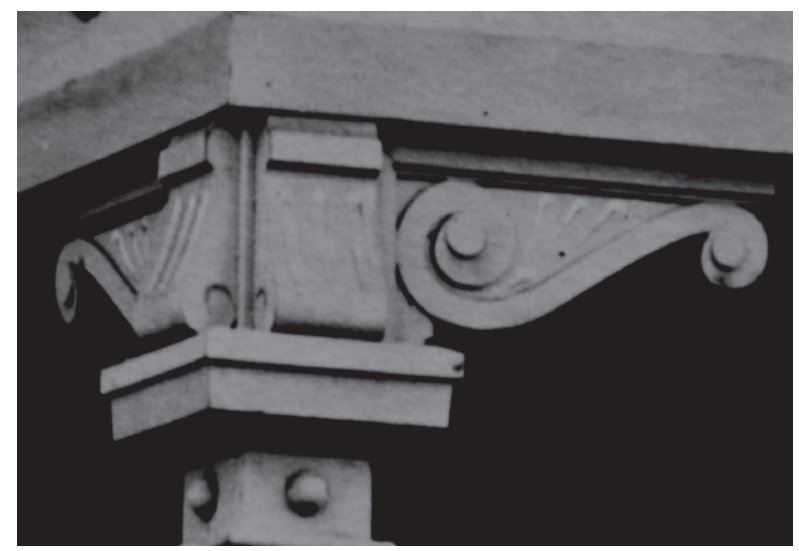

図 8 玄関ポーチ横向き渦型持ち送り 


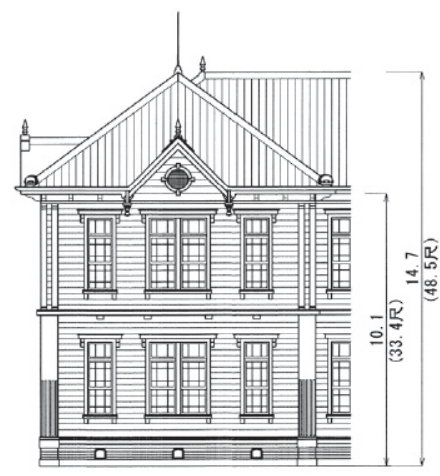

図 9 熊本高等工業学校本館東翼家(単位 $\mathrm{m}$ )

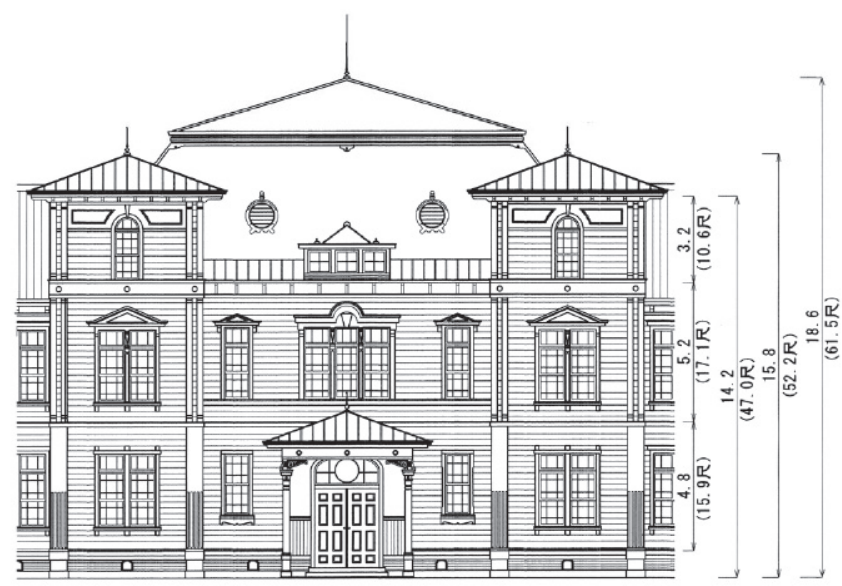

図 10 熊本高等工業学校本館中央家(単位 $\mathrm{m}$ )
いた付け柱、2 階 3 階は 2 本のトスカナ風付け柱がある。

東西の翼家は、 1,2 階とも北側壁面の中央に 2 連空、その両側に 単空を配置している。また隅角部は正面の双塔の 1,2 階部分と同様 の構成となっている。屋根は宝形で、壁面上部の中央には頂部に装 飾がついた小破風を持つ。この小破風部分には上下左右に楔形の装 飾がついた円形の換気口がある。

玄関部正面の重要な構成要素である双塔とマンサード屋根に着目 し、当時の他の文部省直轄諸学校と比較してみる。本館に双塔形式 を採用しているのは熊本高等工業、米沢高工、東京盲の 3 校である。 米沢高工及び東京盲は明治 43 年の完成であるので、熊本高等工業は 双塔形式が採用された最も早い例といってよい。なお、本館以外の 校舎では鹿児島高農講堂、東京美校金工科に双塔があり、熊本高等 工業本館はこれらの先駆けとなったものである。後に述べるように 熊本高等工業の設計者太田次郎吉は、明治 28 年から帝国大学工科大 学に勤務しており、明治 21 年(1888)建設の辰野金吾設計による工科 大学本館が双塔形式を採用しているところから、あるいは、何らか の影響を受けたのかもしれない。

マンサード屋根については、明治 20 年代においては一高、三高に 採用されたもののその後中断し、明治 36 年(1903)の東京高師、東京 高工において復活寸る。それ以降、明治 40 年代において名古屋高工、 長崎高商、熊本高等工業、仙台高工、米沢高工とこの時期多くの学 校において採用されている。

\section{8 設計者、施工者}

\section{8-1 設計者}

明治 39 年 11 月 16 日付けの九州日日新聞 ${ }^{74)}$ には「文部省建築課熊 本出張所は本月一日より高等工業學校内の一部に於て開所し文部省 技手太田治郎吉氏外數名にて同校新築設計中なるが新築校舎の位置 模様等は目下製圖中にして未だ確定に至らざるも(後略)」との記載 がある。表 1 のとおり文部省建築課長の久留正道が熊本に来たのは 明治 39 年(1906) 4 月か 5 月 ${ }^{75)}$ であり、文部省建築課の熊本出張所が 開設されるのは同年 11 月、また土地の地均し工事が熊本県から発注 されるのが明治 39 年(1906)11 月である。この一連の動きの時間的経 緯からも、また上記熊本出張所開設を伝える記事中の文からも、校 舎の設計は文部省建築課の熊本出張所が担当したものと考えられ
る。前述した本館の南側廊下も、前述の「學校建築圖説明及設計大 要」により北側廊下を主導した文部省本省の建築課による設計でな く、出張所による設計のため実現したものとも考えられる。

この熊本出張所の責任者太田次郎吉は明治 39 年(1906)10月 16 日 から校舎全体が完成した明治 42 年(1909)3 月 17 日まで熊本出張所長 心得として勤務した ${ }^{76)}$ 。太田次郎吉の経歴は、表 2 の通りであり、 その経歴、出張所内の立場からみて本館の設計は、大田次郎吉の手

表 2 太田次郎吉の経歴

\begin{tabular}{|c|c|}
\hline 日付 & 動静 \\
\hline 嘉永 02 年(1849) 11 月 01 日*1 & 武蔵国に生まれる \\
\hline 明治 09 年(1876)12 月 27 日*1 & 群馬県雇土木掛 \\
\hline 明治 13 年 $(1880) 12$ 月 13 日*1 & 宮内省内匠課 \\
\hline 明治 22 年(1889)06 月*2 & $\begin{array}{l}\text { 造家学会入会、長崎県佐世保港日本 } \\
\text { 土木会社出張所 }\end{array}$ \\
\hline 明治 23 年 $(1890) 08$ 月頃*3 & 小野田港日本舎密製造会社建築場 \\
\hline 明治 23 年(1890)11 月頃*3 & 京都上京区麩屋町押小路上ル 21 \\
\hline 明治 26 年(1893)01 月頃*3 & 神田錦町 3 丁目 11 番地 \\
\hline 明治 28 年(1995)08 月 07 日*1 & 帝国工科大学教室建築掛 \\
\hline 明治 32 年(1899)11 月現在*4 & $\begin{array}{l}\text { 京都上京区西三本木丸太町上儿眞町 } \\
21\end{array}$ \\
\hline 明治 33 年(1900)4 月現在*5 & 文部省大臣官房建築課技手 \\
\hline 明治 35 年(1902)03 月 23 日*1 & $\begin{array}{l}\text { 文部省総務局建築課京都出張所物 } \\
\text { 品会計官吏 }\end{array}$ \\
\hline 明治 39 年(1906)10月 16 日*1 & $\begin{array}{l}\text { 文部大臣官房建築課熊本出張所長心 } \\
\text { 得 }\end{array}$ \\
\hline 明治 42 年(1909)03 月 17 日*1 & 文部大臣官房建築課 \\
\hline 明治 42 年(1909)06 月 05 日*6 & 文部技師 \\
\hline 明治 42 年(1909)07 月頃*3 & 文部省建築課秋田出張所 \\
\hline 明治 42 年(1909)11 月頃*4 & 文部省建築課新潟出張所 \\
\hline 明治 44 年(1911)07 月 27 日*3 & 文部省退職 京都市上京区 \\
\hline
\end{tabular}

注)*1 文部科学省資料, *2「造家学会会員名簿」, *3「建築雑誌」, *4「建築学会会員住所姓名表(録)」, *5「職員録」77), *6『日本の大 学キャンパス成立史』 
によると考えられる。

前記の新聞には熊本出張所設立の際、太田次郎吉の他に数名の技 術者がいたとされているが、熊本にいたことが記録として確認でき るのは、珠渕勇二(明治 39 年 11 月 ${ }^{78)}$ 頃から明治 40 年 4 月頃 ${ }^{79}$ まで)、 吉田増太郎(明治 40 年 1 月頃 ${ }^{80}$ から明治 41 年 6 月頃 ${ }^{81)}$ まで)の 2 名で あり、彼らの果たした役割は不明である。

\section{8-2 施工者}

福岡の博多において明治初年創業した岩崎建設(昭和 30 年までは 岩崎組)の社史である『岩崎建設百参拾年史』82) には明治 40 年(1907)6 月から明治 41 年(1908)12 月まで、木造二階建「熊本高等工業学校教 室及事務室石上場以上新築工事」を 49,890 円で請負っていることが 記載されている。前述のとおり「教室及び事務室」という名称は『沿 革史』で使われている用語であり本館に相当する。また、掲示図も 本館部分には「教室及事務室」と書かれている。このことから施工 者は岩崎組と考えられる ${ }^{83)}$ 。

\section{9 まとめ}

明治期、日本が工業化していく過程において、政府は優秀な技術 者を急速に育成するため、実業専門学校として高等工業学校を設立 した。明治 39 年(1906)、その 5 番目及び 6 番目の学校が熊本と仙台 に設立された。熊本では、明治 41 年(1908)に主要な建物が完成し、 明治 42 年(1909)落成式を行った。今回、熊本高等工業学校の掲示図 と写真から本館の平面図と立面図を作成した。この本館は、規模か ら見て、現存する米沢高等工業(建築面積 395 坪)をはるかに上回る (建築面積 481 坪)ものである。平面の外形線は正確に左右対称とし ていること、中央家や翼家に種々の装飾を施し装飾性豊かな校舎で あることは、明治末期の文部省直轄諸学校の校舎のレベルを示す一 例として重要な位置を占めると考えられる。

$$
\text { さらに、以下のことが明らかになった。 }
$$

1) 掲示図は、大正 8 年(1919)から 9 年(1920)頃の校舎の配置状況が描 かれている。その中の本館の外形は創立当時の形を表している。

2) 本館の長さは東西 55 間約 $100 \mathrm{~m}$ 、建築面積は 481 坪約 $1587 \mathrm{~m}^{2}$ で あり、その面積は当時の記録と一致する。

3) 本館の平面的特徵は、南側廊下であることである。これは当時の 文部省の方針に反するものであり、同省直轄の諸学校の中では、 極めて稀な例である。

4) 本館のファサードの大きな構成要素は、マンサード屋根と玄関両 側の双塔である。マンサード屋根は、当時既に多くの学校におい て採用されていたが、双塔は他の学校に先駆けて採用された。

5)設計者は 当時、文部省建築課熊本出張所所長心得だった太田次 郎吉、施工者は福岡の岩崎組と考えられる。

謝辞 本稿の執筆にあたり、資料をご提供いただいた熊本大学五高 記念館、熊本大学工学部研究資料館、東北大学大学院工学研究科飯 㴊康一教授、岩手大学財務部施設管理課、木島千嘉氏、立面図復元 の方法について教示いただいた崇城大学工学部建築学科須鎗敬二技 師、この他調查にご協力いただいた多くの方々に感謝します。

\section{注}

1) 文部省實業學務局編纂『實業教育五十年史』實業教育五十周年記念會、 1934.10、p365

2)「實業教育費國庫補助法」は明治 27 年 6 月 11 日法律第 21 号として公布さ れ (官報第 3284 号明治 27 年 6 月 12 日)、この他「工業教員養成規程」(同 年 6 月 14 日文部省令第 12 号(官報第 3286 号明治 27 年 6 月 14 日))、「徒弟 学校規程」(同年 7 月 25 日文部省令第 20 号(官報第 3321 号明治 27 年 7 月 25 日)）が定められた。

3)官報第 5917 号 明治 36 年 3 月 27 日この栜令により専門学校とされた のは、千葉、仙台、岡山、金沢、長崎の各医学専門学校、東京外国語学校、 東京美術学校、東京音楽学校である。

4)官報 前掲注 3)

5)同栜令で、工業系以外で実業専門学校とされたのは、札幌農学校、盛岡高 等農林学校、東京高等商業学校、神戸高等商業学校である。

6)明治 38 年勅令第 96 号 明治 38 年 3 月 28 日 文部省直轄諸学校官制改正 公布官報第 6520 号 明治 38 年 3 月 29 日

7)明治 39 年栜令第 41 号 明治 39 年 3 月 29 日 文部省直轄諸学校官制改正 公布官報第 6822 号 明治 39 年 3 月 30 日

8)明治 43 年栜令第 66 号 明治 43 年 3 月 26 日 文部省直轄諸学校官制改正 公布官報号外明治 43 年 3 月 28 日

9)明治 45 年栜令第 65 号及び第 66 号 明治 45 年 3 月 29 日 東北帝国大学 官制改正及び文部省直轄諸学校官制改正公布 官報第 8631 号 明治 45 年 3 月 30 日

10)私立の工業専門学校は、明治専門学校(明治 40 年 7 月認可) と早稲田大学 理工科(明治 41 年 5 月認可) 2 校があった。

11)宮本雅明「明治期における文部省営繥組織の構成と沿革 高等教育施設 の史的研究(1)」日本建築学会論文報告集、第 292 号、pp.119 - pp.128、1980.6。 宮本雅明「明治期における文部省営繕組織の活動体制 高等教育施設の史 的研究(2)」日本建築学会論文報告集、第 297 号、pp.131 - pp.138、1980.11。 宮本雅明「明治中期の高等中学校にみる高等教育施設の成立過程 高等教 育施設の史的研究(3)」日本建築学会論文報告集、第 304 号、pp.137 -pp.147 1981.6。宮本雅明、谷直樹、石田潤一郎「山本治兵衛の建築活動と明治後 期における高等教育施設の外観意匠 高等教育施設の史的研究(4)」日本建 築学会論文報告集、第 310 号、pp.152 - pp.160、1981.12。

12)宮本雅明『日本の大学キャンパス成立史』、(財)九州大学出版会、1989.4

13)菅野誠『日本学校建築史』、(株)文教ニュース社、1973.8

14)前掲注 12)『日本の大学キャンパス成立史』 p133

15)前掲注 12)『日本の大学キャンパス成立史』 p184

16)前掲注 12)『日本の大学キャンパス成立史』 p221

17)前掲注 13)『日本学校建築史』 pp.438一pp.439 なお、ここには建物名称 として「機械実習工場」と記載されているが、後述の熊本高等工業学校関 係資料では全て「機械実験工場」という名称が使われているため本文でも 「機械実験工場」とした。

18）「文部省直轄諸學校官制」明治 26 年 8 月 25 日栜令第 86 号、この官制に 基づく学校は、明治末には、高等師範が東京、広島、東京女子、奈良女子 の 4 校、高等農業系が盛岡、鹿児島、上田虫糸の 3 校、高等商業が東京、 神戸、長崎、山口、小樽の 5 校、高等学校が 8 校、医学専門が千葉、岡山、 金沢、長崎、新潟、の 5 校、高等工業系が東京、大阪、京都工芸、名古屋、 熊本、米沢、秋田鉱山の 7 校、その他東京外語、東京美術、東京音楽、東 京盲、東京聾喂の 5 校、全体で 37 校あった。

19)竣工は大正元年であるが、明治 45 年と同一年のため、ここに掲げた。 20)明治 30 年文部省令第 3 号 明治 30 年 4 月 17 日 同日付け官報第 4134 号

21)前掲注 20)明治 30 年文部省令第 3 号

22)第五高等学校規則第 1 章第 2 条(第五高等學校『第五高等學校一覧自明治 30 年至明治 31 年』、1898.2、p11) なお、明治 30 年文部省令第 6 号明治 30 年 5 月 17 日(同日付け官報第 4159 号)では学科及び講座の数を定めると しているが、学科目とその講座数は定められているものの学科名は明示さ れていない。

23)工学部入学細則第 3 条 前掲注 22)『第五高等学校一覧 自明治 30 年至 明治 31 年』p50

24)第五高等學校『第五高等學校一覧 自明治 32 年至明治 33 年』、1900.12の 付図

25)熊本高等工業學校編輯兼發行『熊本高等工業學校沿革史』、1938.4、p.92 26)文部省總務局文書課『日本帝國文部省第 28 年報 自明治 33 年至明治 34 
年』、1902.4 p70

27)明治 39 年文部省令第 2 号 明治 39 年 3 月 31 日 同日付け官報第 6823 号 28)前掲注 7)明治 39 年勅令第 41 号

29)明治 39 年文部省令第 9 号 明治 39 年 6 月 2 日 同日付け官報第 6876 号 30)前掲注 25)『熊本高等工業學校沿革史』p131

31)九州日日新聞明治 38 年 12 月 12 日号に明治 39 年度政府予算の紹介があ り、その中に「金三萬八千五百圓 熊本工業專門學校創立費 但総額十九 萬千圓にして明年度以降四十一年度に亘る繼續費なり」との記述がある。

32)前掲注 25)『熊本高等工業學校沿革史』p99 なお、『熊本県議会史第二巻』 (熊本県議会事務局編纂 1968.8)によれば明治 38 年 11 月の通常県会に第 25 号議案「明治 39 年度歳入歳出追加予算」が提出された。これは「三十 九年度に本県内に高等工業専門学校が設置される場合に、敷地を買収して 寄付することとしたためである。この議案は原案通り可決された。同書 pp.1206-1207

33)前掲注 25)『熊本高等工業學校沿革史』pp.101一 102

34)官報号外 明治 39 年 3 月 13 日

35 九州日日新聞 明治 39 年 11 月 23 日

36)九州日日新聞 明治 40 年 4 月 7 日に「地均し外廓とも既に全く竣工」と いう記事がある。

37) 官報第 6836 号 明治 39 年 4 月 17 日 なお、「建築雑誌」第 233 号 明 治 39 年 5 月「會員異動々靜」欄 p298 では 4 月 17 日とされている。

38 この出張は、明治 39 年 4 月 21 日(官報第 6841 号明治 39 年 4 月 23 日「官 吏發着」欄)から同年 5 月 12 日(官報第 6859 号明治 39 年 5 月 14 日「官吏 發着」欄)まで 22 日間であり、この間 6 市をまわることはかなりの強行日 程である。一方、熊本高等工業学校校長中原淳蔵は 5 月 1 日(官報第 6851 号明治 39 年 5 月 4 日「官吏發着」欄)から同年 6 月 22 日(官報第 6895 号明 治 39 年 6 月 25 日「官吏發着」欄)まで東京にいたため、あるいは実質の 打合せは東京で行なわれたのかもしれない。

39)九州日日新聞 明治 39 年 11 月 16 日 また、「建築雑誌」第 240 号 明治 39 年 12 月「轉居」欄 $\mathrm{p} 835$ に「准員 太田次郎吉君 熊本市外黒髪村文部 省建築課熊本出張所」の記載がある。

40)前掲注 25)『熊本高等工業學校沿革史』p148

41)九州日日新聞明治 41 年 6 月 26 日「熊本高等工業學校の本舘の工事は此程 落成を告げ(以下略)」という記事がある。

42)熊本高等工業學校『熊本高等工業學校一覧 自明治 41 年至明治 42 年』、 1909.2、p3

43)前掲注 25)『熊本高等工業學校沿革史』

44)前掲注 25)『熊本高等工業學校沿革史』pp.149 - 150

45) 官報第 7617 号明治 41 年 11 月 14 日 なお、「建築雑誌」第 264 号明治 41 年 12 月号「會員動靜」欄 p505では 11 月 13 日とされている。

46)この出張は、明治 41 年 11 月 18 日(官報第 7622 号明治 41 年 11 月 20 日 「官吏發着」欄)から同年 12 月 8 日(官報第 7638 号明治 41 年 12 月 10 日「官 吏發着」欄)まで 21 日間である。

47)前掲注 25)『熊本高等工業學校沿革史』p150

48)前掲注 25)『熊本高等工業學校沿革史』p151

49)前掲注 25)『熊本高等工業學校沿革史』p180、九州日日新聞明治 42 年 4 月 18 日

50)前掲注 42) 『熊本高等工業學校一覧 自明治 41 年至明治 42 年』に掲載さ れた「熊本高等工業學校平面圖」。なお、各年の学校一覧には縮尺 $1 / 1000$ の「熊本高等工業學校平面圖」が掲載されているが、建物は外形線のみで あり、配置図と呼んだ方が適切である。

51)国の重要文化財「熊本大学工学部(旧熊本高等工業学校)旧機械実験工場附 工作機械一式」平成 6 年指定

52 )火災は大正 11 年 10 月 11 日未明、九州日日新聞 同年同月 12 日 九州新 聞 同年月日

53)九州日日新聞 大正 7 年 4 月 6 日

54) 前掲注 25)『熊本高等工業學校沿革史』p264

55)木島家所蔵

56)文化庁編集兼発行『重要文化財 旧米沢高等工業学校本館保存修理工事 報告書』、1987.2

57)岩手大学財務部施設管理課蔵

$58)$ 學校一覧』の明治 41 年版 1 枚、明治 44 年版 1 枚、大正元年版 2 枚。『沿 革史』6 枚。創建当初の写真と思われる市販の絵葉書写真 3 枚(熊本大学五 高記念館蔵)。『熊本大学工学部百年史』(熊本大学工学部創立百周年記念事 業実行委員会・記念誌部会編『熊本大学工学部百年史』熊本大学工学部創 立百周年記念事業後援会 2000.8)掲載写真 3 枚。熊本高等工業学校卒業記
念アルバム(熊本大学工学部研究資料館蔵)のうち機械工学科大正 9 年 3 月のもの 10 枚、大正 10 年 3 月のもの 10 枚、土木工学科大正 10 年 3 月の もの 1 枚。『冨重利平作品集』掲載写真(荒木精之編『冨重利平作品集』冨 重利平作品集刊行会 1977.10 p87)1 枚。『熊本・歴史と魅力』掲載写真(熊 本日日新聞情報文化センター編『熊本・歴史と魅力』熊本市・熊本市市 制 100 周年実行委員会 1989.10 p89)1 枚。

59)前掲注 55)の図面 なお、この建物は故木島安史氏が熊本大学在職中に移 築したもので、同氏によって孤風院と名付けられた。この図面は、同氏著 『孤風院白書』住まいの図書館出版局、1991.4、p41に掲載されている。

60)前掲注 56)『重要文化財 旧米沢高等工業学校本館保存修理工事報告書』 p50,173,175,197,199 等

61)前掲注 56) 『重要文化財 旧米沢高等工業学校本館保存修理工事報告書』 p4 には仕様書にある名称として紹介され、同書で使われており、本論でも この名称を使用する。

62)継ぎ目部分は、図の寸法で 1 ヶ所では約 $9 \mathrm{~mm}, 1$ ヶ所では約 $2 \mathrm{~mm}$ 縮んで いた。

63)前掲注 25)『熊本高等工業學校沿革史』p149 ここには木造二階建 458 坪、 三階建 18 坪、平家建 5 坪と記載されている。このうち、平家建は車寄せ 部分、三階建は立関両側の塔の部分、二階部分はそれ以外の部分である。 各年の『學校一覧』では、これらを合計した 481 坪が記載されている。な お、これらの面積が建築面積であることは、設立当時の建物としてそのま ま現存する旧書庫(二階建て、れんが造)の建築面積 20 坪で確認した。

64)米沢高等工業学校においても、教室が外部に面している南側は空の間隔 が均一ではない。前掲注 56)『重要文化財 旧米沢高等工業学校本館保存 修理工事報告書』

65) 荒木精之編『富重利平作品集』冨重利平作品集刊行会、1977.10、p87 66)作図方法を模式図により示す。

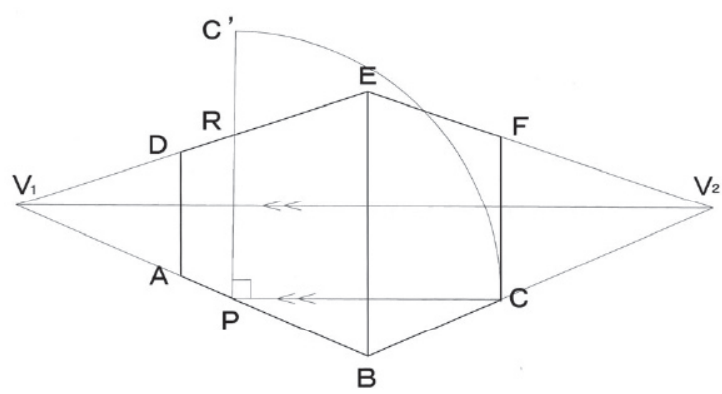

(1) 図形 $\mathrm{ABCDEF}$ は写真に写っている直方体で、高さ方向の歪みはないも のとし、二点透視図で描かれているものとみなす。

(2) 二つの消点 $V_{1} 、 V_{2}$ を求める。

(3) 直線 $\mathrm{V}_{1} \mathrm{~V}_{2}$ と平行な線を $\mathrm{C}$ から引き、直線 $\mathrm{AB}$ との交点を $\mathrm{P}$ とする。

(4) P 点から直線 PC に垂直な線を引き、直線 PC と等しい寸法の点を C'と する。 $(\mathrm{PC}=\mathrm{PC}$ ')

(5) $\mathrm{PC}$ と $\mathrm{DE}$ の交点を $\mathrm{R}$ とする。

(6)平面図上で $P$ 点に相当する点を決定し、PC に相当する寸法を求める。

(7)現実のPR の寸法/現実の PC'の寸法(=現実の PC の寸法 : 既知数)

=図上の PR の寸法 / 図上の PC'の寸法

という比例関係が成立つので、現実の PR の寸法が求まり、

$\mathrm{PR}=\mathrm{AD}=\mathrm{BE}=\mathrm{CF}$ となる。

(8)これを基に、種々の高さ方向の寸法を求めることが可能になり、立面図 が描ける。

67)前掲注 12)『日本の大学キャンパス成立史』

68)前掲注 13) 『日本学校建築史』p375

69)文部大臣官房會計課発行(奥付は會計課であるが、冒頭の緒言では會計課 建築掛とある)1895.4 第一章總説の(五)に「教室ノ形状八長方形卜シ室ノ 方向八南又八西南、東南卜シ(後略)」、(二十一)には「廊下は幅六尺以上二 シテ間内廊下トシ(後略)」と記載されている。

70)第 5325 号 彙報欄の學事に掲載されている。

71)青木正夫「文部省は学校建築の発展に何をしてきたか」「建築雑誌」 1326 号 1992 年 4 月号 $\quad$ p.51

72)本館火災後、大正 12 年建設され現存している本館は北側廊下となってい る。しかし、熊本県においては、その後も南側廊下がつくられた例があり、 現存するものでは大正 12 年建設の代陽小学校校舎や戦前の旧制中学のう 
ち唯一現存する昭和 12 年建設の旧玉名中学本館(現熊本県立玉名高校本館、 国登録文化財)がある。なお、明治 30 年第五高等学校工学部開設の際建設 され、熊本高等工業学校南校舎として移築された校舎は、五高時代も熊本 高等工業時代も北側廊下であった。(『第五高等学校一覧』中の略図と掲 示図)

73)大正時代の写真では 3 連空となっているが、当初は 2 連空であった。

74)前掲注 39) なお、前掲注 12)『日本の大学キャンパス成立史』p73には、 この記事が掲載された新聞は前掲注 25)『熊本高等工業學校沿革史』に記 載されているとおうに「地方新聞」と記載されているが、この記事が実際 掲載された新聞名は九州日日新聞である。

75)久留正道に対する地方への出張命令は、熊本を含んだものは明治 39 年 4 月 16 日と明治 41 年 11 月 13 日とがある。その間に、明治 39 年 7 月 19 日、 明治 40 年 2 月 14 日、同年 11 月 13 日、明治 41 年 5 月 2 日、同年 6 月 12 日、8 月 13 日、同年 9 月 30 日の計 7 回地方への出張命令があるが、いず れも熊本は出張先となっていない。

76)文部科学省大臣官房人事課による。なお、「建築雑誌会員」動静欄によれ ば、明治 39 年 12 月号に熊本への転居、明治 42 年 4 月号に文部省への転 居が掲載されている。

77)内閣印刷局発行

78 )明治 39 年 11 月 24 日現在調ベ明治 39 年版「建築学會々員住所姓名録」熊 本県第五高等学校内文部省建築課出張所 なお、珠淵と吉田の人事記録は 文部科学省にはない。

79)「建築雑誌」明治 40 年 5 月号 東京一転居している。

80)「建築雑誌」明治 40 年 2 月号 熊本文部省建築課出張所

81)「建築雑誌」 41 年 7 月号 東京へ転居している。
82)「岩崎建設百参拾年史」岩崎建設株式会社発行 1998.5 p47, p286

83)なお、岩崎組は、熊本高等工業とほぼ同時期に、れんが造の熊本地方裁判 所庁舎新築工事も施工している。また、戦前の熊本において、三大請負の 一つと称される飯田組の遺族の家には、本館の東南部にあったれんが造の 特別試金室の写真が残されているので、この部分は飯田組の可能性があ る。

\section{図版等出典}

図 1 熊本高等工業學校『熊本高等工業學校一覧 自明治 41 年至同 42 年』、 1909.2 黒塗りは筆者記入

図 2 熊本大学工学部研究資料館蔵 掲示図

図 3 筆者指導により、崇城大学工学部建築学科 4 年生岩下泰子、吉田圭也、 熊本大学大学院修士課程末藤武志の諸君の作図による。

図 4 図 3 に同じ

図 5 図 3 に同じ

図 6 荒木精之編『冨重利平作品集』冨重利平作品集刊行会、1977.10、 p87

図 7 熊本大学工学部創立百周年記念事業実行委員会・記念誌部会編『熊本 大学工学部百年史』熊本大学工学部創立百周年記念事業後援会 2000.8 グラビア写真

図 8 熊本大学工学部研究資料館蔵 掲示写真

図 9 図 3 に同じ

図 10 図 3 に同じ 